\section{Editorial/Éditorial}

\section{The National Forest Congress}

The National Forest Congress has come and gone. Its proceedings will appear in English in the Forestry Chronicle and in French in Forêt Conservation. In this issue, Dr. R.J. Bourchier outlines the program and gives his impressions of the Congress. My impressions were somewhat different.

Many of the papers were excellent. Discussion following the presentations was frequently stimulating. I have never before sat through so rivetting a forestry session as that staged by the "BC talent show" on employment. Jack Webster was outstanding as the provocative chairman. No one could fail to be moved by Jack Munro's passionate indictment of a "heartless" industry for its indifference to the plight of longterm employees laid off with a minimum of benefits. Equally moving in a different way was Graham Bruce's exhortation to carry the story of forestry to the public - how he lost an election for MLA in British Columbia l'll never understand. Unfortunately, these two latter messages will probably never appear in print because both speakers abandoned their scripts.

As Bob Bourchier points out in his paper, events like the Congress seldom produce dramatic break-throughs, but are valuable in raising the consciousness of the public and politicians on the importance of good forestry and in providing reference points on the road to responsible forest management. $\mathrm{He}$ is right. Nevertheless the end of the Congress left me with a feeling of disappointment. This is why.

The Prime Minister opened the first session on trade with a polished and amusing address. But he said nothing new no mention of a federal Department of Forestry that we all were waiting for. (We shall have to push hard during the next few months if we wish to see that.) There was almost an element of intellectual dishonesty in the way he and other ministers bandied impressive figures for expenditures on forest management without once mentioning that these were to be spread over five years.
In the same session, everyone seemed to express grave concern over Canada's falling share of world markets in forest products. As the size of the world market grows and more countries get into the act, Canada's percentage share must inevitably fall. What counts is that we maintain or increase the absolute amount of our exports and that we can sell them at a profit - but no one said that.

In discussing wood supply, some members of industry still seemed to question whether Canada has a problem, although this has been documented to death. And I become very tired of hearing industry officials moan that they cannot be expected to invest in forestry when they lack security of tenure. This is a red herring. In most of Canada, big industry has security of tenure as long as it lives up to the terms of its license agreements.

There was a conspicuous absence of tough questions thrown at the panels, particularly the panel of forestry ministers, which almost sounded like a love-in. For example, all agreed that more R \& D is a must, but no one asked why government and industry aren't hiring more researchers. Again, better forest management is a must, but where are the foresters and technicians in the woods to make it possible? The provinces have reduced rather than increased forestry staff and no one questioned industry's deplorable hiring record in light of its increasing management responsibilities.

I was also disappointed in the Congress' publicity. At most meetings of this importance, there is usually a continuing flow of press releases. I don't recall having seen any at the Congress despite a firm having been hired to handle publicity. And I hardly saw a mention of the meeting in the Ottawa Citizen, Globe and Mail or the Montreal Gazette.

I hope the Congress will prove to be the milestone that its organizers and participants expected. But unless the forestry world maintains and increases its efforts to carry the forestry story to government and the public, I fear that it will have no more impact than the 1966 Montebello Conference.

I.C.M. Place

\title{
Forest Policy Developments
}

\section{New Forestry Legislation Introduced in Nova Scotia}

On 3 February, 1986, the Honourable Kenneth Streatch, Minister of Lands and Forests, announced a new forest policy for Nova Scotia, based largely on the recommendations of the Nova Scotia Royal Commission on Forestry. ${ }^{1}$ On 17 April, he tabled three new bills in the Provincial Legislature to implement the new policy. These new bills are the 'Forest Enhancement Act', the Forests Act and the Act to Establish the Nova Scotia Primary Forest Products Marketing Board.

See The Forestry Chronicle 62(2): 76-78

\section{Forest Enhancement Act}

The umbrella legislation for the new forestry policy is the Forest Enhancement Act. Replacing the Forest Improvement Act, this is designed to:

- develop a healthier, more productive forest;

- support private landowners in making the most productive use of their woodlands; 
- encourage good forest management of private lands as the primary source of supply for the forest products industry;

- maintain or enhance wildlife and their habitats, water quality, and recreational activities; and

- double forest production by the year 2025, thereby creating more jobs.

The new act provides for appointment of a Commissioner of Forestry Enhancement and establishment of a Forestry Advisory Council. The Council will have nine members namely: one private woodland owner, one representative of the forest industries, one professional forester, one silviculture contractor, one wildlife representative and four members at large. Its function is to advise the Minister on the adequacy of forest management programs, forestry education, research, environmental protection, wildlife and wildlife habitat, and matters of forest policy and strategy.

The role of the Commissioner of Forest Enhancement will be to facilitate implementing forest management programs, coordinate the activities of the Council with those of the government, and to report annually to the Governor-inCouncil through the Minister on the implementation of forest management programs.

According to the act, forest management programs in the province shall be based on the following principles:

scheduling harvesting of stands at the optimum time;

- allocating stands to the most beneficial end use;

- creating a suitable environment for more orderly and efficient marketing of forest products;

- a continuing vigorous silviculture program:

- the importance of protecting the forest from fire, insects, diseases and unwanted competing vegetation, and

- the importance of making the best economic use of all primary forest products harvested.

The forest management techniques to be used on Crown lands and recommended for private lands shall:

- favour suitable natural reproduction wherever practical and involve selective or shelterwood harvesting systems;

- permit consideration of the size and configuration of areas to be clearcut where circumstances warrant;

- ensure that planting is undertaken where sites are not expected to regenerate adequately on their own;

- provide for early spacing or clearing where this is needed;

- provide for weeding in stands to be managed;

- provide for commercial thinning to enhance future sawlog harvest where stand and site conditions permit;

- reflect prevailing hazards from insects, diseases and fire control and related protection requirements, and provide appropriate information and advice to forest land owners and occupiers; and

- provide for maximum utilization of primary forest products harvested.

The Act also makes it mandatory for the Council to advise the Minister on:

- developing guidelines and standards to minimize the impact of forestry practices on wildlife habitats and the environment;

- undertaking any cooperative projects on wildlife habitat protection and management;

- provision for special management zones along lakes, rivers and streams in the management planning process; and

- management of forest vegetation on Crown lands adjacent to public highways to make them visually attractive and demonstrate forest management practices to the travelling public.

\section{The Forests Act}

The second bill, the Forests Act, amends but repeats much of the existing Lands and Forests Act. It is 14 pages long and only an outline is possible here. It repeats the principles and techniques for forest management in Nova Scotia already given above from the Forest Enhancement Act. It allows for the following restructuring of the Department of Lands and Forests

- establishment of a Strategic Studies Division under a senior employee to direct and coordinate policy and program development, and to conduct strategic studies to support development and use of forest products and promote better marketing;

- appointment of a Chief Forester to supervise forest management programs, including resource planning, silviculture, research and protection; and

- establishment of a Forest Extension Division under a senior employee to improve the government's ability to help the province's 33000 woodlot owners and to promote public awareness of forestry.

Under Section 5, the Minister shall be responsible for the development and implementation of forest management programs, including:

(a) encouraging and assisting private landowners to manage their land more effectively by providing professional and technical advice and assistance, training programs and financial incentives;

(b) entering into agreements with the Government of Canada to jointly fund forest management programs;

(c) entering into agreements with group management ventures to provide for more effective management of woodlots served;

(d) prevention, detection and suppression of forest fires;

(e) protection of forest land from insects and disease;

(f) providing for forest inventories and associated forest planning activities;

(g) conduct forest research on behalf of the province;

(h) the development and operation of forest nurseries; and

(i) any other matter assigned pursuant to this Act and the regulations.

Of these items, only (d), (e) and (f) are mandatory. However, under Section 10, "the Minister shall ensure that wildlife, wildlife habitats and long-term diversity and stability of forest ecosystems, water supply watersheds and other significant resources are managed." Under Section 20, provision is also made for greater assistance to wood processing industries through the Timber Loan Board.

\section{N.S. Primary Forest Products Marketing Board}

This Act has been introduced to amend Chapter 15 of the Pulpwood Marketing Act. Its scope is broad and it will cover all forest products. The objective of the Act is to ensure that all private woodlot owners will have a fair share of the market and a reasonable return from the sale of primary forest products. It will achieve this through the organization, funding and registration of bargaining agents, and the resolution of 
bargaining disputes. A new bargaining procedure will be provided consisting of a series of steps designed to encourage disputing buyers and sellers to reach agreement among themselves.

The new Primary Forest Products Marketing Board itself will consist of seven members - one each from the sawmill and pulp and paper industries, two woodlot owners, three members not engaged in production, marketing or processing wood products, and a full-time chairman. Working with the provincial Trade Development Authority, the Board will have a broad role in marketing of forest products. It will be subject to audit by the Auditor-General, and bargaining units will be required to provide the Board with audited statements prepared by chartered accountants.

The legislation also includes an "unfair practices" provision to ensure that there is no retaliation or discrimination by either buyers or sellers.

\section{Comments}

The Nova Scotia Government is to be commended for introducing promptly legislation to implement its new forest policy. The new legislation is broad in scope and largely seems to reflect both the spirit and content of the Conservancy Policy advocated by the Royal Commission on Forestry. There are, however, some differences that may prove important. For example, rather than establish an Inspectorate of Woods separate from the Department of Lands and Forests to monitor all aspects of forest management, the Government will appoint a Commissioner of Forest Enhancement and a Forest Advisory Council. The Commissioner will report to the Governor-in-Council through the Minister of Lands and Forests and obviously will have less independence than would an Inspector of Woods reporting directly to the Legislature.

In restructuring the Department of Lands and Forests, the Royal Commission recommended appointing a Deputy Minister of Forestry with responsibility for all forestry matters and a Deputy Minister of Lands responsible for all other functions of the Department of Lands and Forests not assigned to the Deputy Minister of Forests. The legislation tabled allows for appointing a Chief Forester to supervise forest management programs and for creating a Strategic Studies Division and a Forest Extension Division, each under a senior employee. Presumably these three officials will all report directly to the Deputy Minister of Lands and Forests. This arrangement is administratively simpler than that suggested by the Royal Commission, but puts less emphasis on the importance of forest management. A Chief Forester has less clout than a Deputy Minister of Forestry.

On a minor note, the language of the legislation is occasionally loose or inconsistent. For example, one cannot provide "protection for forest land from insects and disease" (Forests Act, Section 5[e]), but one can protect forests from them. Section 9(a) of the Forest Act uses the term "selection cutting" which has a well-defined silvicultural meaning; Section 9(a) of the Forest Enhancement Act uses selective cutting which is virtually meaningless.

Despite these comments, I think the legislation is basically good. The Minister of Lands and Forests will have a strong mandate to implement a progressive forest policy always providing the Cabinet gives him the men and money to do it. And in the final analysis, this depends on the voting public.

I.C.M. Place

\section{Letters/Lettres}

\section{March, 1986}

Mr. Peter C. Newman,

Maclean's Magazine

Maclean Hunter Building.

777 Bay Street.

Toronto, Ontario

M5W 1 A7

\section{Dear Mr. Newman,}

While I understand that you reside in my old stamping ground of Cordova Bay, B.C., this is the only address that is readily available to me.

Christmas 1985 was a "book" year for me, and among my new acquisitions is your "Company of Adventurers". While other distractions have severely limited the time I have been able to devote to reading and enjoying this monumental work of yours on a subject that has intrigued me since my childhood in British Columbia, I am writing to inquire of you the purpose you might have had in mind in including the mythical story about Ed Bovey and the "local bushwhacker" in your Foreword on page ix.

While you go on to state that "Edmund Charles Bovey later become (became) one of the more enlightened pillars of the Canadian Establishment", he certainly was not very enlightened at the time of this occurrence if he in fact did believe that tree branches moved up the tree as "the little spruce quiefly continued growing - and growing"!
As you tell this anecdote with an apparently straight face, not betraying a trace of disbelief as you recite this fairy tale, I am left with the distinct impression that you might believe it to be true. This is not entirely incomprehensible, for I have been assured by science students in both Hawaii and Malaysia, who should have known better, that trees such as the Hawailan ohia whose seeds germinate atop the tree-fern, 20-30' in the air, and then send their roots down the moss-covered fern to the ground, did not rise up on those roots, like a person getting up on stilts. In like manner, it seems, Ed Bovey and his assistant seem to have rationalized that the frying pan was lifted up circa $40^{\prime}$ in the air by the black spruce tree! A rare feat, if it could be accomplished!

Yours sincerely, J.W. Kerr 760 Golf Club Rd. RR3 Fredericton N.B. E3B $4 \times 4$

February 10, 1986

Dear Mr. Ker:

Many thanks for your recent letter. I give up. I'm sure you're right, and I'm most grateful that you took the trouble to write. The "frying pan" story will mysteriously disappear from the next edition!

As ever,

Peter C. Newman 